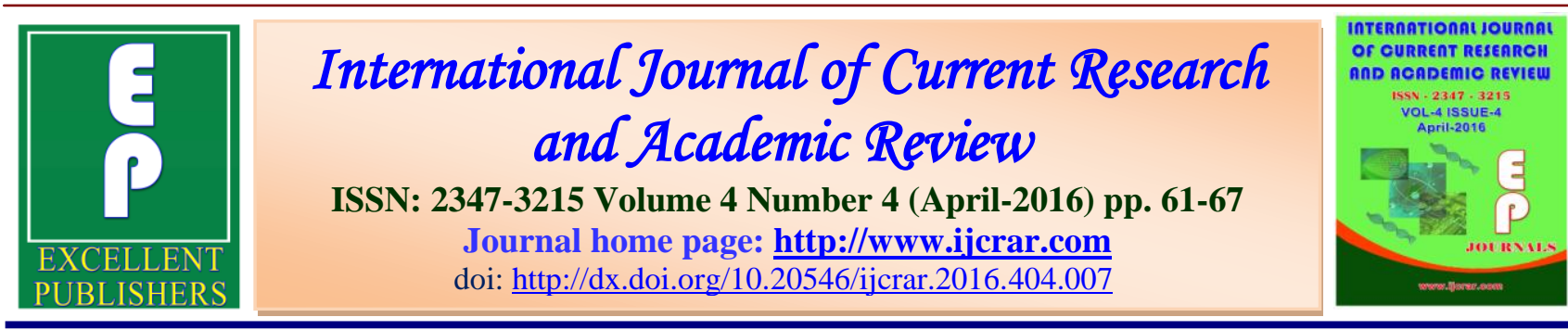

\title{
Vermicomposting: A new trend towards Management of Agricultural Waste (Paddy Straw)
}

\section{Maya M. Jaybhaye and Satish A. Bhalerao*}

Environmental Science Research Laboratory, Department of Botany, Wilson College, Mumbai-400007, University of Mumbai, M.S., India

*Corresponding author

\begin{tabular}{|c|c|}
\hline KEYWORDS & A B S T R A C $T$ \\
\hline $\begin{array}{l}\text { Agricultural waste, } \\
\text { castings, } \\
\text { Eisenia foetida, } \\
\text { Organic matter, } \\
\text { Vermicomposting. }\end{array}$ & $\begin{array}{l}\text { The increasing rate of agricultural wastes due to the large scale of } \\
\text { urbanization and a consequence of economic development has become a } \\
\text { problem that produces the huge quantities of waste in India and causes a } \\
\text { serious environmental problem which is difficult for management. } \\
\text { Management of agricultural waste has become one of the biggest problems. } \\
\text { Vermicomposting is the best option to deal with this problem. } \\
\text { Vermicomposting involves stabilization of organic waste through the joint } \\
\text { action of earthworms and aerobic micro-organisms. Vermicomposting is } \\
\text { environment friendly and cost effective technique for agricultural waste. } \\
\text { Vermicompost is better option for the chemical fertilizer because it is not } \\
\text { associated with any kind of pollution. Agricultural waste such as Paddy straw } \\
\text { selected for the present research work, it was pre-decomposed for } 40 \text { days } \\
\text { followed by subsequent vermicomposting for } 30 \text { days. Earthworms are } \\
\text { capable of transforming of garbage into gold. Eisenia foetida is the most } \\
\text { commonly used species of earthworm for vermicomposting. Temperature } \\
\text { maintained at } 26^{\circ} \mathrm{C} \text { with the moisture content of } 60-80 \% \text {. Earthworm's } \\
\text { breakdown organic matter and leaves behind castings that are an } \\
\text { exceptionally valuable fertilizer. Physico-chemical analysis shown decreased } \\
\text { in TOC, C:N ratio and increased in NPK content of the vermicompost } \\
\text { compared to compost and initial agricultural waste (Paddy straw). } \\
\text { Vermicomposting has many applications in crop improvement such as } \\
\text { pathogen destruction, water holding capacity of soil, improved crop growth } \\
\text { and yield, improved soil physical, chemical and biological properties and } \\
\text { production of plant growth regulators. }\end{array}$ \\
\hline
\end{tabular}

\section{Introduction}

The increasing rate of agricultural wastes due to the large scale of urbanization and a consequence of economic development has become a problem that produces the huge 
quantities of waste in India and causes a serious environmental problem which is difficult for management. The increasing rate at which organic wastes are generated has become a problem for disposal and/or management. Indian agriculture is the largest private sector enterprise in the country of over 110 million farmers. Crop residues are generated in large quantities and constitute an abundant but underutilized source of renewable biomass in agriculture. The amount of crop residues available in India is estimated to be approximately 620 million (Pandey A., et al., 2009). Currently, the management and disposal of agricultural waste production is one of the most critical environmental issues. Therefore, the study related on safe reuse and management of agricultural waste is important. According to Appelhof (1981), the appropriate disposal of waste should involve both maximum cost effective recovery of recyclable constituents and transformation of non-recoverable material into forms, which do not present environmental hazards.

The major agricultural sources are livestock and human wastes, crop residues, tree wastes and aquatic weeds, green manures, urban and rural wastes, agro-industrial byproducts, marine wastes and tank silt. With the introduction of high yielding varieties and adoption of intensive systems of cropping, large quantities of crop residues such as straw, leaves twigs and stubbles along with huge amounts of grasses and weeds are readily available on farms. According to a conservative estimation, around 600 to 700 million tons (mt) of agricultural waste (including $272 \mathrm{mt}$ of crop residues) are available in India every year, but most of it remains unutilized.

\section{Types of Agricultural Wastes}

Agricultural wastes are those which come out from agricultural field and associated areas. The major agricultural sources are livestock and human wastes, crop residues, tree wastes and aquatic weeds, etc.

Composting is the process of decomposition and stabilization of organic matter under controlled condition. Composting is a controlled biological decomposition process that converts organic matter to a stable, humus-like product and the process depend upon microorganisms, which utilize decomposable organic waste both as an energy and food source (Sajnanath and Sushama, 2004).

Organic matter present in agricultural wastes, this waste can be recycled by the method of composting, which is one of the oldest forms of disposal. Apart from being clean, cheap, and safe, composting can significantly reduce the amount of disposable waste.

Vermicomposting involves stabilization of organic waste through the joint action of earthworms and aerobic micro-organisms. Recycling of agricultural wastes using earthworms has become an important component of sustainable agriculture which has a multidirectional impact in terms of safe disposal of wastes, preventing environmental pollution besides providing nutrient rich materials. Although microbes are responsible for biochemical degradation of organic matter, earthworms are the important drivers of the process, conditioning the substrate and altering the biological activity (Suthar, S., 2007).

\section{Materials and Methods}

\section{Collection of Agricultural Waste (Paddy straw)}

Collected from the local supplier (Ghatkpoar), Mumbai. Paddy straw waste 
Int.J.Curr.Res.Aca.Rev.2016; 4(4): 61-67

chopped into $2-3 \mathrm{~cm}$ pieces for the experimental purpose.

Collection of Earthworms: Eisenia foetida earthworms were collected from the local supplier, Panvel. Around 45 earthworms collected for the experimental purpose.

Experimental set up: 3 experimental drums prepared in which $1 \mathrm{~kg}$ waste added per drum. This set up kept for 40 days of composting process. Throughout the experiment temperature maintained and moisture content upto 60 to $80 \%$. Turning/Aeration was done manually after every 4 days. After 40 days compost collected and packed the sample for further analysis. In the same experimental drum 15 earthworms were added in each drum and kept for 30 more days.

Physico-chemical Analysis: Initial paddy straw, compost and vermicompost analysis done by following methods:

\section{Results and Discussion}

The Bagasse, compost and vermicompost were analyzed for various parameters and the results are indicated in the Table 3.
There was difference in nutrient composition of compost and vermicompost.

The $\mathrm{P}^{\mathrm{H}}$ of the initial paddy straw was 6.35 and compost and vermicompost of the paddy straw followed by 6.97 and 6.77 , which is neutral and suitable for earthworms. The electrical conductivity of vermicompost was 4.57 which were more than initial paddy straw and compost such as 0.80 and 0.85 .

Moisture content of the vermicompost was $70.33 \%$ and for paddy straw it was $8 \%$ followed by compost 53\%. Kale and Krisnamoorthy (1981) have demonstrated that earthworm castings have excellent moisture holding capacity.

The TOC of the paddy straw had decreased in the composting and vermicomposting process such as from $29.74 \% \rightarrow 27.39 \% \rightarrow 17.38 \%$. As well as C:N ratio also decreased from $52.17 \% \rightarrow 38.02 \% \rightarrow 23.25 \%$. TKN was increased from $0.57 \% \rightarrow 0.67 \% \rightarrow 0.75 \%$ and TP also showed rise such as $0.05 \% \rightarrow 0.15 \% \rightarrow 0.30 \%$. Along with this TK increased in order as $0.48 \% \rightarrow 0.50 \% \rightarrow 0.56 \%$.

Table.1 List of Wastes Tested for Vermicomposting

\begin{tabular}{|c|c|}
\hline sources of Agricultural Wastes & Utilizable wastes for vermicomposting \\
\hline Agricultural fields & $\begin{array}{c}\text { Stubbles, weeds, husk, straw and farmyard } \\
\text { manure }\end{array}$ \\
\hline Plantations and Gardens & Stems, leaf, fruit rinds, stubbles, grass clippings \\
\hline Animal waste & Dung, urine and biogas slurry \\
\hline Urban solid waste & $\begin{array}{c}\text { Kitchen waste from households and restaurants, } \\
\text { waste from market yards and places of worship } \\
\text { and sludge from sewage treatment plants }\end{array}$ \\
\hline
\end{tabular}

(Source: Kale, R. D., 1994) 
Int.J.Curr.Res.Aca.Rev.2016; 4(4): 61-67

Table.2 Methodology for Physico-Chemical Analysis

\begin{tabular}{|c|c|c|}
\hline No & Parameter & Methodology \\
\hline 1. & $\mathrm{P}^{\mathrm{H}}$ & $\mathrm{P}^{\mathrm{H}}$ Meter \\
\hline 2. & Electrical conductivity & Conductivity meter \\
\hline 3. & Moisture content & Gravimetric method \\
\hline 4. & Total organic carbon (TOC) & Walkey and Black's Titration method \\
\hline 5. & Total Kjeldahl Nitrogen (TKN) & --------------- \\
\hline 6. & Carbon Nitrogen Ratio (C:N) & Olsen's Method by Spectrophotometer \\
\hline 7. & Total Phosphorus (TP) & Flame photometer \\
\hline 8. & Total Potassium (TK) & \\
\hline
\end{tabular}

Jackson, M. L. 1975 (Soil Chemical analysis, New Delhi: Practice Hall of India)

Table.3 Comparision of Compost and Vermicompost of Paddy Straw

\begin{tabular}{|c|c|c|c|c|}
\hline \multirow{2}{*}{$\begin{array}{c}\text { Sr. } \\
\text { No. }\end{array}$} & \multirow[t]{2}{*}{ Parameters } & \multirow{2}{*}{$\begin{array}{c}\text { Paddy straw } \\
\text { initial value } \\
(\%)\end{array}$} & \multicolumn{2}{|c|}{ Values In Percentage (\%) } \\
\hline & & & Compost & Vermicompost \\
\hline 1. & $\mathrm{P}^{\mathrm{H}}$ & 6.35 & $6.97 \pm 0.24$ & $6.77 \pm 0.48$ \\
\hline 2. & Electrical conductivity & 0.80 & $0.85 \pm 0.02$ & $4.57 \pm 0.21$ \\
\hline 3. & Moisture content & 8.0 & $53 \pm 2.64$ & $70.33 \pm 1.52$ \\
\hline 4. & Total organic carbon (TOC) & 29.74 & $27.39 \pm 0.79$ & $17.38 \pm 0.68$ \\
\hline 5. & Total Kjeldahl Nitrogen (TKN) & 0.57 & $0.67 \pm 0.07$ & $0.75 \pm 0.05$ \\
\hline 6. & Carbon Nitrogen Ratio (C:N) & 52.17 & $38.02 \pm 8.58$ & $23.25 \pm 1.83$ \\
\hline 7. & Total Phosphorus (TP) & 0.05 & $0.15 \pm 0.01$ & $0.30 \pm 0.11$ \\
\hline 8. & Total Potassium (TK) & 0.48 & $0.50 \pm 0.03$ & $0.56 \pm 0.03$ \\
\hline
\end{tabular}

Note: All values are mean and standard deviation of three replicates $(\mathrm{M} \pm \mathrm{SD})$

Figure.1 Paddy Straw Initial Sample

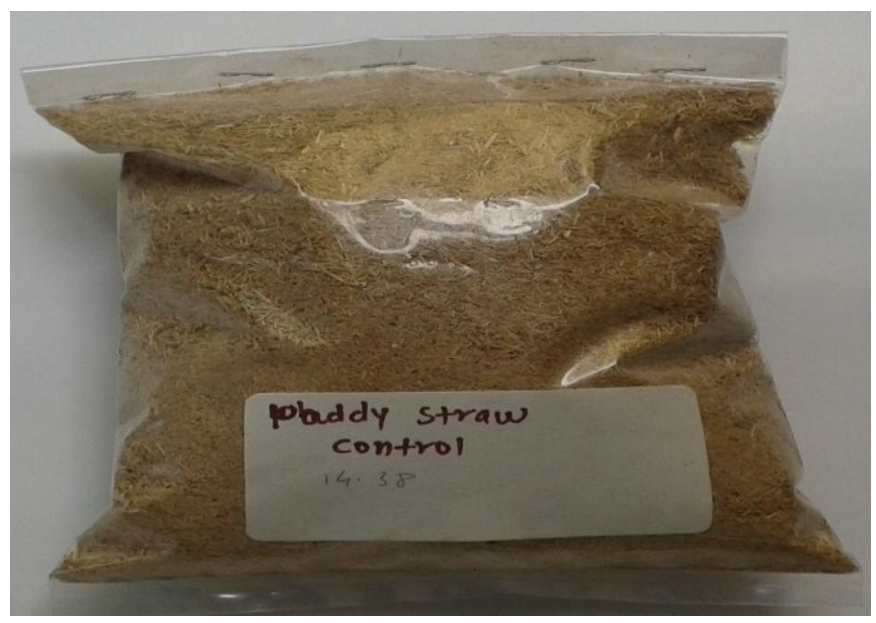




\section{Int.J.Curr.Res.Aca.Rev.2016; 4(4): 61-67}

Figure.2 Earthworm (Eisenia foetida) used for Vermicompost Production

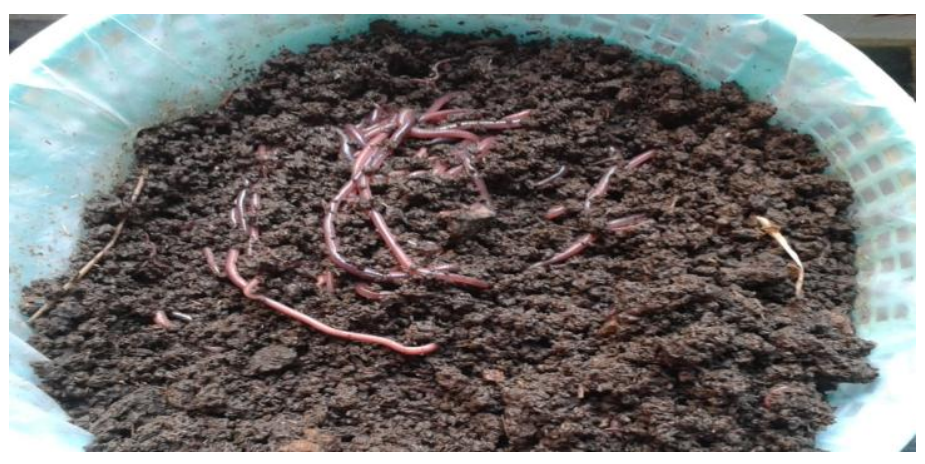

Figure.3 Process of Paddy Straw Composting for 40 Days

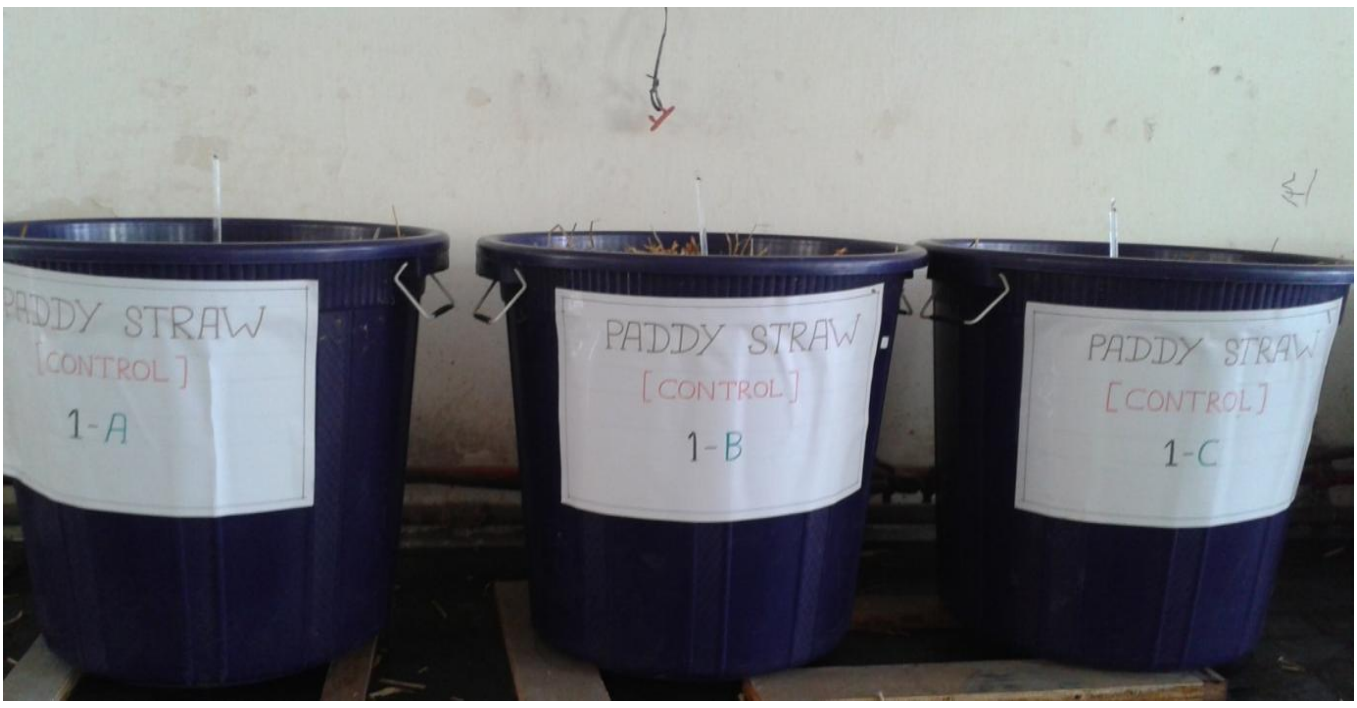

Figure.4 Physico-Chemical Analysis of Initial Paddy Straw, Compost and Vermicompost

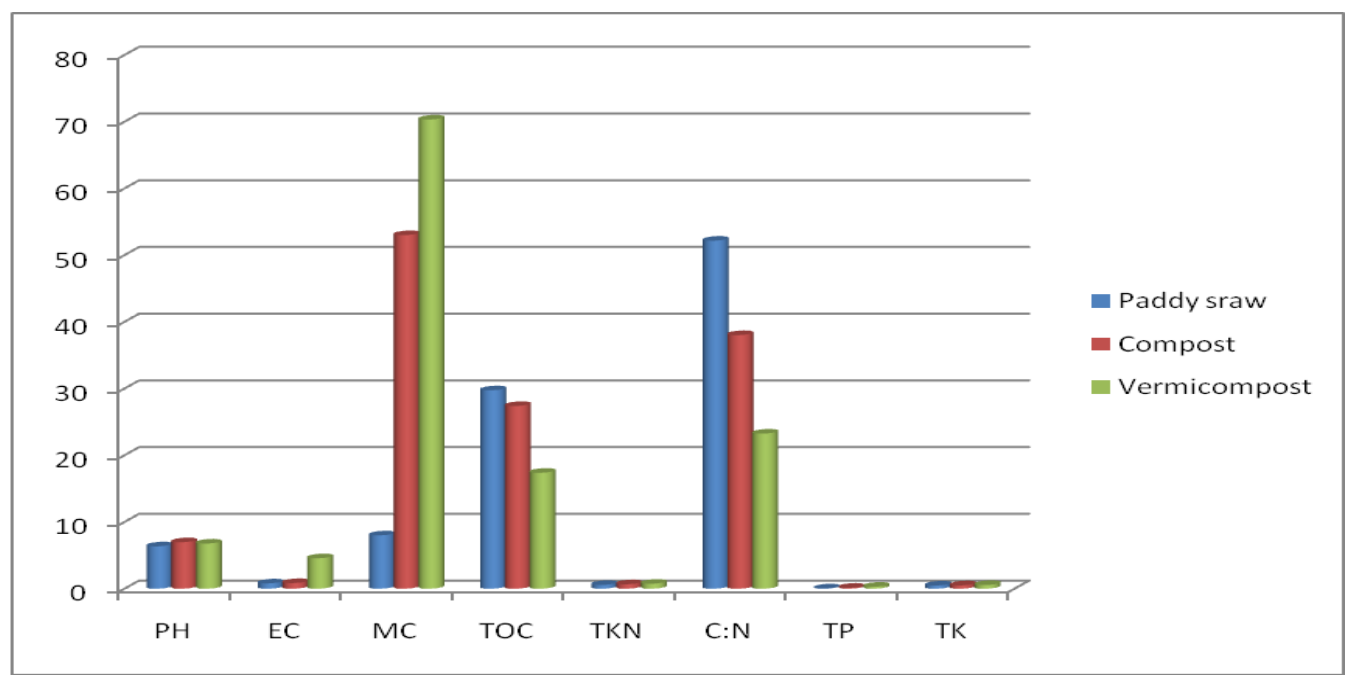


Earthworm species like $E$. foetida, $A$. diffringens and $E$. eugineae decomposed all types of agricultural wastes into compost efficiently (Karthikeyan, 2000). The castings are rich in nitrate, phosphorus, potassium, calcium and magnesium (Misra et al., 2003). Gunadi et al. (2002) also demonstrated that after six months of vermicomposting, the nitrogen content in the end product was high.

It was reported that the $\mathrm{C}: \mathrm{N}$ ratio narrow down as nitrogen remain in the system, while some of the $\mathrm{C}$ is released as $\mathrm{CO}_{2}$ (Sadasivam and Manickam, 1993). The available $\mathrm{P}$ was also higher in the vermicompost as compared to the initial feed (Suthar S. and Singh S., 2008). Muthukumaravel et al. (2008) reported that vermicomposted vegetable waste contain more phosphorous than untreated fresh vegetable waste.

\section{Conclusion}

The tendancy of earthworms to decompose agricultural waste was studied by using paddy straw along with Eisenia fetida under laboratory conditions. Vermicomposting is an advantageous technology for waste management. The vermicompost of paddy straw showed many fold increase in some important plant nutrients than simple composting, which suggests that the product can be used as potential plant growth media.

This study revealed that vermicomposting technology could be used efficiently to combat the problem of agricultural waste management. It can be concluded that vermicomposting technology is the one of the more economic, eco-friendly waste management technology and resulting in the bioconversion from waste to wealth.

\section{Acknowledgement}

The author is thankful to the head and my guide Dr. Satish A. Bhalerao sir, department of Botany, Wilson College, University of Mumbai. He always encouraged me for my research work.

\section{References}

Appelhof, M. 1981. Workshop on the role of earthworm in the stabilization of organic residues. Vol. I, Proceedings, Beech Leaf Press, Michigan, USA, 315.

Gunadi, B., Edwards, C.A. 2002. The effect of multiple application of different organic waste on the growth fecundity and survival of Eisenia foetida (Savigny) (Lumbricidae). Pedobiologia, (31): 199-209.

Kale, R.D., Krishnamoorthy, R.V. 1981. Enrichment of soil fertility by earthworm activity, G.K., V.K, USA Tech. No. 37: 64-68.

Kale, R.D. 1994. Vermicomposting of wastes materials. Earthworm Cindrella of organic farming, Prism book pvt. Ltd, New delhi, India, 47.

Karthikeyan, S. 2000. Compost maturity indices. In: Short Courseon Vermiculture and Vermicomposting Technology, Tamil Nadu Agricultural University, Coimbatore. p. 98.

Misra R.V., Roy, R.N., Hiraoka, H. 2003. On-farm Composting Methods Food and Agriculture Organization of the United Nations (FAO), Rome, pp. 135.

Muthukumaravel, K., Amsath, A., Sukumaran, $\quad$ M. 2008. Vermicomposting vegetable waste using cow dung E-j Chem, 5(4): 810813. 
Pandey, A., Biswas, S., Sukumaran, R.K., Kaushik, N. 2009. Study on Availability of Indian Biomass Resources for Exploitation: A Report Based on a Nationwide Survey TIFAC, New Delhi.

Sadasivam, S., Manickam, A. 1996. A Biochemical Methods, New Age International (P) Ltd., Publishers, $2^{\text {nd }}$ Edn.

Sajnanath, K., Sushama, P.K. 2004. Recycling of bio-waste through vermicomposting. Agrobios News Lett., Vol. 3, No. 3: 33-35.

Suthar, S., Singh, S. 2008. Vermicomposting of domestic waste by using two epigeic earthworms Perionyx excavates and $P$. sansibaricus. Int. J. Environ. Sci. Tech., 5(1): 99-106.

Suthar, S. 2007. Vermicomposting potential of Perionyx sansibaricus (Perrier) in different waste materials. Biores. Tech., 98: 1231-1237.

\section{How to cite this article:}

Maya M. Jaybhaye and Satish A. Bhalerao. 2016. Vermicomposting: A New Trend Towards Management of Agricultural Waste (Paddy Straw). Int.J.Curr.Res.Aca.Rev.4(4): 61-67. doi: http://dx.doi.org/10.20546/ijcrar.2016.404.007 